http://dx.doi.org/10.11646/phytotaxa.163.3.4

\title{
Notes on Phyllanthera (Apocynaceae) from the upper Sepik of Papua New Guinea: P. lancifolia and P. piforsteriana sp. nov.
}

\author{
WAYNE TAKEUCHI \\ Harvard University Herbaria, 22 Divinity Avenue, Cambridge, MA 02138, USA; email: wtnewguinea@hotmail.com
}

\begin{abstract}
Phyllanthera piforsteriana (Apocynaceae) is described from the Sepik River basin in Papua New Guinea. Distributional notes are also provided for $P$. lancifolia, a frequent associate of the new species but otherwise rarely represented in herbarium collections.
\end{abstract}

Key words: Cryptolepis, new species, Periplocoideae

\section{Introduction}

Phyllanthera Blume (1826: 1048) is a genus of 9 vining species collectively ranging from Southeast Asia to Australia (Ionta 2009). With a conspectus of 7 species, New Guinea is the generic center of diversity.

A colorful species of Phyllanthera was recently discovered during a multi-year schedule of expeditions to the upper Sepik. In the following discussion, Phyllanthera piforsteriana is formally described from these exploratory surveys. Distributional and taxonomic notes are also briefly presented for P. lancifolia (Forster 1991: 381) Venter (2001: 566), a rarely seen congener despite being a common and characteristic vine in Sepik habitats where it occurs.

\section{Methods}

Taxonomic descriptions are based on the measurements and qualitative attributes from dried specimens (excepting flower measurements from bottled collections). Characters determined in situ from living plants are reported separately as 'field characters'.

The corolla tube measurements are expressed as: length $\times$ basal width $\times$ distal width (at the sinus). The similar protocol for the filaments is: length $\times$ basal width $\times$ distal width (at the anthers).

Silica-dried leaf samples have been inserted with the $\mathrm{M}$ duplicate for Takeuchi et al. 25595; the A and L duplicates for Takeuchi et al. 25729; and the K duplicate for Takeuchi et al. 25732. Ethanol-preserved flowers in leakproof vials are attached to the A duplicates for Takeuchi et al. 25595 and 25732.

Phyllanthera lancifolia (P.I.Forst.) Venter (2001: 566). Fig. 1.

Cryptolepis lancifolia Forster (1991: 381). Type:-INDONESIA. Papua Province: Okwalimkan River headwaters, lower montane forest, on moss covered branches of low trees, $5^{\circ} 02^{\prime} \mathrm{S}, 140^{\circ} 55^{\prime} \mathrm{E}, 4000 \mathrm{ft}$ (1220 m), 17 June 1967, Ridsdale et al. 31999 (holotype L; isotype LAE! [2 sheets]).

Additional specimens examined: PAPUA NEW GUINEA. Southern Highlands Province: South Karius, montane alluvial forest, $5^{\circ} 59.324 ' \mathrm{~S}, 142^{\circ} 40.287^{\prime} \mathrm{E}, 1365 \mathrm{~m}, 6$ February 2008, Takeuchi et al. 22487 (A!, LAE!); 7 February 
TABLE 1. Summary of the principal distinctions between Phyllanthera piforsteriana and the species closest to it $(P$. takeuchiana).

\begin{tabular}{|c|c|}
\hline Phyllanthera piforsteriana W.N.Takeuchi & Phyllanthera takeuchiana P.I.Forst. ${ }^{1}$ \\
\hline $\begin{array}{l}\text { known only from the upper Sepik (northern PNG) at 625- } \\
1100 \mathrm{~m}\end{array}$ & 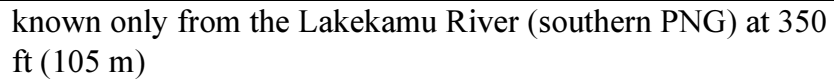 \\
\hline $\begin{array}{l}\text { leaf surfaces (in vivo) adaxially dark dull green, abaxially } \\
\text { purple or purple red }\end{array}$ & $\begin{array}{l}\text { leaf surfaces (in vivo) adaxially dark dull green, abaxially } \\
\text { pale green to glaucescent }\end{array}$ \\
\hline $\begin{array}{l}\text { leaves with } 10-22(-27) \text { secondary veins per side, diverging } \\
(50-) 65-85^{\circ} \text { from midribs }\end{array}$ & $\begin{array}{l}\text { leaves with } 32-39 \text { secondary veins per side, diverging } 75-90^{\circ} \\
\text { from midribs }\end{array}$ \\
\hline $\begin{array}{l}\text { corolla united in the lower } 3.5-5 \mathrm{~mm} \text {; lobes obliquely elliptic, } \\
5.2-7.2 \times 3.2-3.9 \mathrm{~mm} \text {, not papillate }\end{array}$ & $\begin{array}{l}\text { corolla united in the lower } 1-2.5 \mathrm{~mm} \text {; lobes elliptic-ovate, } 9- \\
11 \times 5-6 \mathrm{~mm} \text {, adaxially densely papillate }\end{array}$ \\
\hline gynostegium $2-2.2 \times 2.2-2.5 \mathrm{~mm}$, sessile & gynostegium ca. $3 \times 4 \mathrm{~mm}$, inserted on a $2 \mathrm{~mm}$ long stipe \\
\hline $\begin{array}{l}\text { filaments } 0.4-0.7 \mathrm{~mm} \text { long; anthers } 0.4-0.6 \times(0.5-) 0.7-0.9 \\
\mathrm{~mm} \text {; apical appendages acute, elliptic-ovate }(\text { distinctly more } \\
\text { long than wide), } 0.6-0.8 \times 0.3-0.6 \mathrm{~mm}\end{array}$ & $\begin{array}{l}\text { filaments ca. } 1.5 \mathrm{~mm} \text { long; anthers ca. } 1.5 \times 1.5 \mathrm{~mm} \text {; apical } \\
\text { appendages obtuse, broadly flabellate (distinctly more wide } \\
\text { than long), ca. } 1.2 \times 1.8 \mathrm{~mm}\end{array}$ \\
\hline
\end{tabular}

${ }^{1}$ extracted from Forster (2002), and refined by examination of the LAE isotype.

\section{Acknowledgments}

The Sepik botanical surveys of 2009-2010 were sponsored by Xstrata Copper. My participation on the field itinerary was also supported by the Arnold Arboretum and the Harvard University Herbaria.

Francis Crome (ornithologist) was the senior investigator and principal planner for the terrestrial studies. My colleagues in the field also included Ken Aplin (mammalogist), Chris Müller (entomologist), Stephen Richards (herpetologist), Michael Sale (Coffey Natural Systems liaison), and Iain Woxvold (ornithologist and team leader).

\section{References}

Blume, C.L. (1826) Bijdragen tot de flora van Nedelandsch Indie 16. Batavia, ter Lands Drukkerij, pp. 942-1169.

Brown, R. (1810) On the Asclepiadeae, a natural order of plants separated from the Apocineae of Jussieu. [Pre-print of: Memoires of the Wernerian Natural History Society 1: 12-78 (1811)].

Forster, P.I. (1990) Notes on Asclepiadaceae, 2. Austrobaileya 3: 273-289.

Forster, P.I. (1991) Cryptolepis lancifolia (Asclepiadaceae: Periplocoideae), a new species from Irian Jaya. Blumea 35: 381383.

Forster, P.I. (1993) Conspectus of Cryptolepis R. Br. (Asclepiadaceae: Periplocoideae) in Malesia. Austrobaileya 4: 67-73.

Forster, P.I. (2002) Phyllanthera takeuchiana (Apocynaceae: Periplocoideae), a new species from Papua New Guinea. Austrobaileya 6: 329-331.

Hammermaster, E.T. \& Saunders, J.C. (1995) Forest Resources and Vegetation Mapping of Papua New Guinea. PNGRIS Publ. 4. CSIRO and AIDAB, Canberra, $294 \mathrm{pp}$.

Ionta, G.M. (2009) Phylogeny Reconstruction of Periplocoideae (Apocynaceae) Based on Morphological and Molecular Characters and a Taxonomic Revision of Decalepis. Ph.D. Dissertation, University of Florida, 169 pp.

Schumann, K.M. (1905) Klasse Dicotyledoneae. In: Schumann, K.M. \& Lauterbach, K. (eds.) Flora der Deutschen Schutzgebiete in der Südsee. Gebrüder Borntraeger, Leipzig, pp. 237-403. http://dx.doi.org/10.5962/bhl.title.717

Venter, H.J.T. \& Verhoeven, R.L. (2001) Diversity and relationships within the Periplocoideae (Apocynaceae). Annals of the Missouri Botanical Garden 88: 550-568.

http://dx.doi.org/10.2307/3298633 